\title{
SUCCESS THROUGH FAILURE
}


The Road Taken: The History and Future of America's Infrastructure

The House with Sixteen Handmade Doors:

A Tale of Architectural Choice and Craftsmanship

To Forgive Design: Understanding Failure

An Engineer's Alphabet: Gleanings from the Softer Side of a Profession

The Essential Engineer:

Why Science Alone Will Not Solve Our Global Problems

The Toothpick: Technology and Culture

Pushing the Limits: New Adventures in Engineering

Small Things Considered: Why There Is No Perfect Design

Small Things Considered: Why There Is No Perfect Design

Paperboy: Confessions of a Future Engineer

The Book on the Bookshelf

Remaking the World: Adventures in Engineering

Invention by Design: How Engineers Get from Thought to Thing

Engineers of Dreams: Great Bridge Builders and the Spanning of America

Design Paradigms: Case Histories of Error and Judgment in Engineering

The Evolution of Useful Things

The Pencil: A History of Design and Circumstance

Beyond Engineering: Essays and Other Attempts to Figure without Equations

To Engineer Is Human: The Role of Failure in Successful Design 


\title{
SUCCESS THROUGH FAILURE The Paradox of Design
}

\author{
With a new preface by the author
}

\author{
Henry Petroski
}

PRINCETON University Press $\leftrightarrow \quad$ Princeton and Oxford 


\section{Copyright (C) 2006 by Henry Petroski}

New Princeton Science Library edition, with a new preface by the author, copyright (C) 2018 by Henry Petroski

Requests for permission to reproduce material from this work should be sent to Permissions, Princeton University Press

Published by Princeton University Press, 41 William Street,

Princeton, New Jersey 08540

In the United Kingdom: Princeton University Press, 6 Oxford Street, Woodstock, Oxfordshire OX20 1TR

All Rights Reserved

Library of Congress Control Number: 2017961434

First printing, 2006

First paperback printing, 2008

First Princeton Science Library paperback printing, 2018

New preface by the author, 2018

New paperback ISBN: 978-0-691-18099-1

Cover images courtesy of iStock, cover design by Michael Boland for thebolanddesignco.com

British Library Cataloging-in-Publication Data is available

Small portions of this material appeared first in American Scientist,

Harvard Business Review, and the Washington Post Book World

This book has been composed in Adobe Caslon and Helvetica Neue

Printed on acid-free paper. $\infty$

press.princeton.edu

Printed in the United States of America

135579108642 
